\title{
MERRY-GO-ROUND
}

THE changes in the composition of the British Government made public on August 28 are unlikely to have much direct effect on the interests of science and technology in the months ahead. On the whole, the gains seem nicely balanced by the losses. The most worrying change is the departure of $\mathrm{Mr}$ Anthony Crosland from the Department of Education and Science and his replacement by Mr Patrick Gordon Walker, if only because it introduces the biggest uncertainty in the new pattern. Since he went to the Department of Education and. Science nearly three years ago, Mr Crosland has won for himself a reputation which engendered something akin to a sense of security among those associated with the department. Almost the only blot on his copybook-but a big one-is the pigheaded decision that university fees would be increased (by a factor of roughly three) for students from overseas. By way of compensation, Mr Crosland seems to have put up a stalwart fight in the past few months to prevent too great an erosion of the educational budget for the financial year ahead, and everybody will be grateful to him for that. He has been an able minister, and his friends will not be the only ones who will be disappointed that he is only being moved sideways, to the Board of Trade, and not upwards to the Department of Economic Affairs. (If Mr Crosland should choose to reconsider his predecessor's decision to build an airfield at Stansted, that will be an uncovenanted benefit of enormous value.)

Mr Gordon Walker is by comparison an unknown quantity. He is scholarly (which should help), donnish (which is if anything a disadvantage), and has such a reputation for loyalty to the Government as a whole that people will naturally fear that he will compromise too readily with other departments. To say this does not imply that compromise is necessarily bad, but merely that in the two years ahead there are bound to be great pressures on the management of resources for expenditure on research in the universities, and that the most reasonable courses of action will not necessarily be the best. The issue of whether the responsibilities of Mr Gordon Walker's department should be transferred to the Ministry of Technology is an obvious snare. There is some logic in it, and obviously there is a great and continuing need of better liaison between the two departments, yet any change in this direction should be vigorously resisted until the Ministry of Technology has shown that it would be able sympathetically to absorb university research without giving in to the temptation to spend the money on something else.

The loss occasioned by the departure of Mr Crosland will to some extent be cancelled out by the simultaneous departure of Mr. Goronwy Roberts, who has for sereral months been concerned with the admini- stration of the research councils. He has not always inspired confidence on scientific matters. $\mathrm{He}$ will be succeeded either by Mrs Shirley Williams or by Miss Alice Bacon, either of whom would be a distinct improvement. Mrs Williams would be a particular asset. She is, after all, the best candidate in sight for the somewhat distant goal of the first woman to be Prime Minister.

For the rest, the reconstruction of the British Government may raise important issues by the changes it will bring about in the balance of power between the economic ministries and the Ministry of Technology. For several months now, and for the best of reasons, the edges between the Ministry of Technology and the Department of Economic Affairs have been confused. Both ministries, for example, are concerned with the economic health of large sections of British industry, the Ministry of Technology by its terms of reference and the Department of Economic Affairs through the working parties which are studying, with varying degrees of success, the functioning of particular sectors of industry - the "little Neddies" as some wag has christened them. Then both ministries claim credit for devising the Industrial Reconstruction Corporation, and the Ministry of Technology has moved steadily, in the three years of its existence, towards the view that the solution to a great many industrial problems is to be found in economics and not in technology in the old-fashioned sense. Yet there are tensions between the ministries as well as common purposes. Should the Ministry of Technology continue to support expensive developments such as the Concord supersonic aircraft, for example? The DEA is likely often to disagree with what the Ministry has to say. In the days when Mr Michael Stewart was in charge at the DEA, the Ministry of Technology may have had its own way too easily. Whether that state of affairs will continue now that Mr. Harold Wilson has decided to take charge of the DEA himself will depend on how much time the Prime Minister can spare for paying attention to the details of his new department's work. His mere presence there, however, could create a more productive relationship between the two departments. With luck, that could be a benefit.

\section{WHAT IS SCIENCE POLICY?}

LORD JACKSON has done a public service in his presidential address to the British Association (see page 1023 ) by drawing attention to the underlying complexity of what people are usually pleased to call science policy. For several years now, but particularly since the governments of several countries have been seek- 
ing ways of keeping the growth-and the cost-of science and technology within what seem to be rcasonable bounds, thore has been a danger that many essential issues would be grossly over-simplified. For example, there has boen a tendency for governments to judge the success of their policies entirely by the size of the fraction of the Gross National Product being spent on research and development. Thus in Britain, it has frequently been held that there is no grcat need to change the scalo of support for science and technology because the magic ratio is not very much greater in the United States. In France, by contrast, where the cost of research and development was a mere $1 \cdot 7$ por cent of the GNP three years ago, comparisons with the United States were one of the principal reasons why the French Government embarked deliberately on a programme to increase the amount of money being spont on science and technology. The danger is that, in thoir preoccupation with these and other yardsticks, those responsible for public administration will overlook the more enduring criteria for deciding what to do and how much to spend.

There is already some evidence in Britain of unhealthy tendencies in directions like these. Lord Jackson has quite properly raised the question of how people should determine the surns of money to be spent on the support of fundamental research, chiefly through the rescarch councils, and this is very much a field in which rules of thumb have recently become fashionable. Recent history is a sufficient explanation of why the administrators are rushing to embrace convenient but possibly misleading yardsticks. Between them tho research councils and the University Grants Committee are now spending the best part of $£ 100$ million on the support of basic research, two-thirds of it in the universities. Expenditure under these headings has been growing more quickly than most othor forms of public expenditure-by 13 per cent or so in the first half of this decade. It did not take long for people to point out that things could not go on like that. In two decades or so, pure rescarch would be costing as much as the National Health Sorvice-that is how the argument used to go. By the ond of the century, scientific research would be consuming the resources of the whole of manufacturing industry. So it was concluded that there must at some stage bo a break in the growth curve. And why not sooner rather than later? For is this not a time when Britain should be spending more on technology (which makes money) and not basic science (which consumes it)? By those and other arguments, it seems to have been agreed that there should now be a deliberate slackening in the pace of growth of spending on science. The troublo is that there is no way of knowing whether this decision is of tho kind that would have done justice to Solomon or whether, on the other hand, it is just a guess.

The objective, of course, is that decisions about the amounts of money to bo spent on university rescarch should ideally be made in the light of a hard-headed appreciation of what university research is for. This is where the numbers are not much help. Thore is no way of escaping the question of why university teachers should be allowed, even encouraged, to devote much of their time to activities which are not strictly pedagogical. Lord Jackson is right in saying that it is not good enough to say that research is always inestimably valuable because nobody can predict what benefits may emerge from it. That is a counscl of unreason.

The real defence of university research must ultimatoly lie in the old dogma that research and teaching are inseparable. If there is anything at all in that assortion, the rapid growth of expenditure on university roscarch in the early sixties is not nearly as outrageous as it sometimes seems to the administrators. The numbers of people teaching science at the universities increased by roughly 9 por cont a year between 1961 and 1965. Is it not reasonable that the expenditure on academic research should have increased by something like 13 per cent a year, especially when account is taken of the inevitable increases of costs from one year to another-the sophistication factor as it is called-now reckoned to account for a steady increase of 4 per cent a year? And what is to happen now that thero are polytechnics as well as universities providing higher education?

Two important conelusions emerge from this. First, the question is not how much the country can afford to spend on academic research, but how much it can afford to spend on higher education. Second, if the policy makors really want to make the best use of public money-as they should-it would be prudent of them to carry out a sensitive field study of the relationship between teaching and research at universities so as to devise meaningful yardsticks for deciding what costs are reasonable.

Similar pitfalls attend the making of policy for the support of industrial resemreh. Here, too, the simpler numbers spell success. Lord Jackson points out, with all due pleasure, that industrial organizations now spend about two-thirds of all the money allocated in Britain to research and development, and that only a third of what they have to spend comes from contracts for defence research. That picture is much more checrful than it used to be even five years ago. But how much of what is being spent is valuable? What, in any case, should be the objectives of industrial research and development? Should the policy makers have it in mind that industrial research is a kind of investment and should they seck to distinguish between successful projects and the failures by calculating some kind of economic return on every investment? By that test it seems fairly clear that many popular technological causes, the Concord supersonic aircraft among them, would be counted not triumphs but a waste of monoy and, what is more important, a misinvostment of men as woll. In other words, in technology much more than in basic science, the sum of money being spent may bo a measure of how many people are occupied on research and development but may say nothing at all about the effectiveness with which they are deployed.

But if the Government and its committees cannot 
take decisions on matters like these, who is to take the risk? Luckily, the experience of the two straitened years just past has helped the British Government to a more realistic appreciation of events than had previously been possible. For one thing, it now seems to be acknowledged that industrial research and development is not really an end in itself, but one of several means by which economic prosperity may be attained, or at least sought.

From this, alas, it follows that decisions about the scale on which research and development should be supported must be made, in the last resort, by people able to calculate the potential rewards and to take the risk of deciding whether to embark on something new. For the most part, the policy makers can only cheer from the sidelines, providing encouragement and some basic help-decent information services and reproducible standards, for example. In the long run, if they really want to encourage the greater use of research and development in industry, they must find somo way of helping enterprises of all kinds to take adventurous decisions. In this context, of course, it does not matter whether an industrial enterprise is nationalized or privately owned - what matters is merely that assessments about the potential value of research and development should rest with the people responsible for day-to-day survival. This is the strongest argument for asking that the Ministry of Technology should now practise what Professor Blackett has been preaching, and take effective steps to channel the talents of the public laboratories into industry.

But what if industry chooses to spend more on research and development than the existing stock of trained men and women can successfully carry out ? This is a reasonable anxiety, if only because it is but a decade since Britain was acutely short of people. In this sense, it is entirely right that Lord Jackson should have dovoted much of his attention to manpower. In the late sixties, however, the old problems have been transformed if not quite melted away. There is now a good deal of slack in the system. Of the 211,000 scientists and engineers at work in Britain in 1965, for example, only 40,000 or so seem to have been employed on industrial research and development. It is hard to think that industry would suddenly run short of people to carry out development if companies collectively decided to increase the scale of their research and development by, say, 50 per cent. It is true that there would be some difficulties, and that companies would have to pay their technical people less meanly, but that is a secondary consideration. It is also true that the men recruited into industry would usually leave some other field of activity bereft, for, even though the system may now be fairly flexible, there is on balance a shortage of trained people. Yet there is also a greater capacity within the system for responding to the changing pressure of demand.

In other words, manpower has almost ceased to be a cause of anxiety in its own right. Instead, it is a field in which the policy makers should be ready to seize the opportunities which may offer themselves.
It is, in particular, a crying need that something more real than lip service should be paid to the principle that the modern world needs an educational system qualitatively different from that which the Victorians invented. The most urgent need is to arrange that all of those who leave schools should know what science and technology are about, that those who leave universities trained as scientists should also know who Keynes was-and Samuelson as well-and that nobody should be required at some over-tender age to declare himself for science, medicine or the humanities without much chance of going back. If there is anything which can be dignified as science policy, it should be the province of men whose real aim is a thorough revolution of the educational system.

In this and a host of other ways, the pursuit of objectives in science policy ends up in fields as different from each other as education and the management of the economy. That is entirely as it should be, for science is no longer a separable part of a nation's activity. It follows, however, that attempts to talk about science policy in isolation from other kinds of policies run the risk of seeming nonsense. But it is also plain that the proper management of scientific resources - a term which is almost entirely synonymous with people-requires that docisions should be made on a small scale and not usually at the centre. Certainly where the fuller exploitation of technology is concerned, the Government must act remotely; there will be trouble if it intervenes too directly on its own accord. In the field of science and technology as a whole, the Government can do much to encourage a more efficient use of facilities for research. Lord Jackson was right to emphasize that in the last resort, a sensible appreciation by the public at large of what science and technology can provide is the only guarantee of good sense. He could well have added that it is equally important that there should be a general appreciation of how science and technology are not almost magical entities in their own right, but, rather, integral parts of national activities of all kinds.

How is the British Government performing by these tests? That is the question which Lord Jackson raised but did not answer. It is fair, however, to acknowledge that in the past two years a great deal has been done to create some useful machinery by means of which sound decisions can be reached. Bodies like the Council for Scientific Policy are working well. It remains to be seen how effectively the Central Advisory Council on Science and Technology will function, but there is at least a chance that good works will be done. Yet it is also plain that the contexts within which these otherwise admirable bodies function are often far too circumscribed. The Council for Scientific Policy, which has a good record for tackling general questions such as the need of computers in universitios and the relationship between universities and government laboratories, has nevertheless fought shy of attempts to influence the quality of teaching in the schools and universities. That may be easier after the Dainton Committee has reported (whenever 
that may be), yet there is no reason why this central issue should not have been tackled long ago. And there remain, of course, outstanding the thorny questions of the scale and the manner in which public funds should be used to support research. In other words, there has been somo progress in the past three years and some of it is valuable, but there is a danger that the British Government and its committeos will interpret the term science policy too literally, and thus attempt to make too many decisions at the centre. What Lord Jackson has been saying may help to push things in the other direction.

\section{ONE STEP ON}

THE announcement in Goneva a week ago that tho Russian and United States Governments have boen able to put forward a draft treaty intended to limit the proliferation of nuclear weapons is a hopeful if small step forward. The Disarmament Committee has been in session at Geneva for so long now that its credibility is much in danger of crosion. If it now becomes the forum for a realistic debate on the extent to which an agreement on the proliferation of nuclear weapons can be successfully controlled by international inspoction or by some other maans, much will have been done to restore its reputation-and the hopes of those outside the conference that some progress on disarmament may eventually be possible.

That said, however, it is inevitable that the weeks ahead will not be comfortable for the delegations represented at Geneva. After several months of private talks, the United States and the Soviet Union have boen forced to admit failure in their attempts to win agreement behind the scenes for the incorporation of safeguards provisions in the treaty they havo tabled. It is no surprise that things have turned out that way (see Nalure, 214, 753; 1967). The United States has plainly failed to win the agreement of the member nations of Euratom that responsibility for inspection and control should be placed with the International Atomic Energy Authority at Vienna, and the Soviet Union is entirely justified in its insistence that it would be improper to delegate this task to Euratom itself.

But this, of course, is only skirmishing. The difficulties ahead are much more serious. The outstanding uncertainty is whether the nations which are not nuclear powers, and which have no intention of making nuclear weapons for themselves, will stomach a treaty which pormanently confirms the nuclear powers in their present grandeur and throws the rest of the world open to international inspection designed to stifle imitative ambitions. The nuclear powers have hithor. to been unreasonably hopeful of what the smaller nations would be happy to accept. For all the cheerfulness which has accompanicd the tabling of tho treaty at Geneva, it remains unlikely that the nuclear powers will be able to win agreement from the smaller nations without making substantial concessions on their own account. But there are technical as well as political problems still to bo resolved. How feasible will it be to design cast-iron inspection systems? How soon could a safeguards system operate? In any case, what value is there in a treaty for the non-proliferation of nuclear explosives which does not include China and France as signatorios?

In the circumstances it would be entirely sensible if the nations now negotiating at Geneva wore to go back almost to the beginning of the discussions about the non-proliferation treaty. To begin with, some years ago, people seemed entirely happy with the notion that a non-proliferation treaty should not include a rigid safoguards system, at least at the beginning. Only when bellicose noises from West Germany had made the Russians take fright, a year or so ago, did the issue of safeguards become a central issue and a stumbling block. But things have changed a great deal in the past twelve months. European nations have clearly becomo much less concorned about the advantages or othorwise of manufacturing nuclear explosives for themselves. So may it not be prudent to think now of a non-proliferation treaty in which the attempt, to design a safeguards system is replaced by somothing less ponderous? This would be something well worth trying for. Ono possible line of compromise would be an international agreement that all nations would make an honest public declaration at regular intervals of all activities connected with the exploitation of nuclear materials. Nuclear powers, for example. would be required every so often to say how much uranium they had converted into a fissile form, and how much of this they had committed to the manufacture of explosivos. By itself, this would do a lot to salve the injured pride of smaller nations. But there is good reason to expect that such a system, operated by the non-nuclear powers and the rest, would be a good assurance that the manufacture of nuclear explosives would not spread. After all, in tho climato of mutual curiosity that would be certain to follow the signing of a non-proliferation treaty, it is extremely improbable that a nation forced to make public declarations of its activities in potentially important fields would be able successfully to keep secret the clandestine manufacture of nuclear explosives. At the same time, there would be good cause to hope that a treaty drawn on comparatively flexible lines like those would serve much more effectively than the cumbersome instrument now being negotiated as a platform from which further forays into disarmament might be attempted. Certainly it would be a great misfortune if there were so much bickering about safoguards in the months ahead at Geneva that the members of the Disarmament Committee would be persuaded to give up once more the hope of signing a treaty to bring the production of nucloar explosives by the nuclear powers under some kind of control. In other words, compromising on a system less rigid than the safeguards now in prospect would be not merely an immediate benefit but an insurance for the future. Will the negotiators seize this opportunity? 